MEDICAL GENETICS IN PRACTICE

\title{
A report of a national mutation testing service for the MEN1 gene: clinical presentations and implications for mutation testing
}

\author{
J W Cardinal, L Bergman, N Hayward, A Sweet, J Warner, L Marks, D Learoyd, T Dwight, \\ B Robinson, M Epstein, M Smith, B T Teh, D P Cameron, J B Prins
}

J Med Genet 2005;42:69-74. doi: 10.1136/jmg.2003.017319

See end of article for authors' affiliations

. D............... Dr J W Cardinal, Department of Diabetes and Endocrinology,

Princess Alexandra Hospital, Ipswich Rd, Woolloongabba, Brisbane 4102, Australia; jcardinal@soms.uq.edu.au

Received

14 December 2003

Accepted for publication

24 May 2004
Introduction: Mutation testing for the MEN1 gene is a useful method to diagnose and predict individuals who either have or will develop multiple endocrine neoplasia type 1 (MEN 1). Clinical selection criteria to identify patients who should be tested are needed, as mutation analysis is costly and time consuming. This study is a report of an Australian national mutation testing service for the MEN1 gene from referred patients with classical MEN 1 and various MEN 1-like conditions.

Results: All 55 MEN1 mutation positive patients had a family history of hyperparathyroidism, had hyperparathyroidism with one other MEN1 related tumour, or had hyperparathyroidism with multiglandular hyperplasia at a young age. We found 42 separate mutations and six recurring mutations from unrelated families, and evidence for a founder effect in five families with the same mutation.

Discussion: Our results indicate that mutations in genes other than MEN1 may cause familial isolated hyperparathyroidism and familial isolated pituitary tumours.

Conclusions: We therefore suggest that routine germline MEN1 mutation testing of all cases of "classical" MEN1, familial hyperparathyroidism, and sporadic hyperparathyroidism with one other MEN1 related condition is justified by national testing services. We do not recommend routine sequencing of the promoter region between nucleotides 1234 and 1758 (Genbank accession no. U93237) as we could not detect any sequence variations within this region in any familial or sporadic cases of MEN1 related conditions lacking a MEN1 mutation. We also suggest that testing be considered for patients $<30$ years old with sporadic hyperparathyroidism and multigland hyperplasia.
M EN1 is a relatively rare autosomal dominant disorder, typically characterised by hyperplasia or tumours of the parathyroid, endocrine pancreas, anterior pituitary, gastrin cells, and neuroendocrine cells. Other less common sites affected include adrenal and adipose tissue. ${ }^{12}$ The prevalence of MEN 1 has been estimated to be 1/30 000 to $1 / 50000 .^{3}$ The disease has been reported to be $52 \%$ and $100 \%$ penetrant by the ages of 20 and 60 years respectively. ${ }^{4}$ However, the clinical presentations are varied and depend largely on the hormones being overexpressed. Mutations in the MENI gene have been shown to be associated with multiple endocrine neoplasia type 1 (MEN 1) and to cause a very similar clinical presentation to MEN 1 in a mouse model. ${ }^{5}$ Thus, as the clinical features of this disease are diverse, genetic screening is a useful method to diagnose patients and to predict the family members who will develop the disease in later life.

MEN 1 predisposing mutations have been demonstrated over the entire nine exons of coding sequence of the MENI gene, making mutation detection an expensive and time consuming process, albeit less expensive than annually screening entire families using biochemical and radiological tests. $^{26}$ Moreover, the clinically heterogeneous nature of the disease makes it difficult to determine appropriate testing criteria, especially for newly presenting patients. Hyperparathyroidism is the most common condition seen in MEN 1, but it is also a common condition generally, with a reported prevalence rate of $0.43 \% .^{7}$ "Classical" MEN 1 presents with a family history of neoplasia of at least two different endocrine cell types, but MEN1 mutations have been shown in patients with familial isolated hyperparathyroidism
(FIHP).$^{8-10}$ In addition, MENI mutations have been shown to have occurred de novo in approximately $10 \%$ of patients. ${ }^{2} 9$ Because of the costs involved, routinely testing all patients with sporadic tumours in MENl related tissues is inappropriate; however, testing only "classical" MENl cases is clearly insufficient.

In this study we report the findings of an Australian mutation testing service after testing for MENl mutations in 150 index cases with MEN1 related conditions. From these data, we suggest clinical criteria to identify patients most suitable for $M E N I$ mutation testing.

\section{METHODS}

\section{Patients}

The index cases included in this report were referred from the Diabetes and Endocrinology Clinic of the Princess Alexandra Hospital or from clinicians throughout Australia and New Zealand. Clinical information was accessed from medical charts with informed consent or confirmed by the referring clinician after the appropriate radiological, biochemical, or histological analysis. Patients were categorised as having persistently elevated hormone levels and tumours of the parathyroid, pituitary, endocrine pancreas, gastrin cells, thymic or bronchial carcinoids, or other miscellaneous tumours of adrenal, adipose, or thyroid origin. Patient consent and ethics approval were obtained locally by the referring clinician.

Abbreviations: FHPT-JT, familial hyperparathyroidism and jaw tumour syndrome; FIHP, familial isolated hyperparathyroidism; MEN 1, multiple endocrine neoplasia type 1 
Data for this report was obtained retrospectively, and as such is subject to the biases of the referring clinicians. Samples from patients with sporadic tumours without any other indication of a germline mutation (such as parathyroid tumours presenting at a young age or multigland involvement) were not received. This report does not include results of predictive testing performed in families after a MENI mutation was found in an index case, as it does not add to the aim of this report.

\section{Mutation analysis \\ DNA extraction and MEN1 gene amplification}

DNA was extracted from peripheral blood leucocytes using the method of Miller et al. ${ }^{11}$ The nine exons of the coding sequence of menin were amplified using PCR as described previously. ${ }^{10}$ The primers for the promoter region and each of the exons have been published previously. ${ }^{8}{ }^{12}$ Reactions were performed in a volume of $50 \mu \mathrm{l}$ and contained $10 \mathrm{mmol} / \mathrm{l}$ Tris- $\mathrm{HCl}, 50 \mathrm{mmol} / \mathrm{l} \mathrm{KCl}, 1.5 \mathrm{mmol} / \mathrm{l} \quad \mathrm{MgCl}_{2}, 250 \mu \mathrm{mol} / \mathrm{l}$ dNTPs, 20 pmol of each primer, 5\% DMSO, 0.5 U AmpliTaq Gold (Perkin Elmer) and approximately $50 \mathrm{ng}$ of template DNA. Cycling conditions were: $94^{\circ} \mathrm{C}$ for 10 minutes, followed by 35 cycles of $94^{\circ} \mathrm{C}$ for 1 minute, $62^{\circ} \mathrm{C}$ for 1 minute, (the annealing temperature for the promoter region and exon 10 was $60^{\circ} \mathrm{C}$, for exon 3 was $58^{\circ} \mathrm{C}$, and for exon 2 was $64^{\circ} \mathrm{C}$ ) and $72^{\circ} \mathrm{C}$ for 1.5 minutes. PCR products were purified using High Pure PCR Product Purification kit (Roche), following the manufacturer's instructions.

\section{DNA sequencing}

Reaction conditions for cycle sequencing were as follows: 200-300 ng of PCR product, $2.5 \mathrm{pmol}$ primer and $4 \mu \mathrm{l}$ of Big Dye Terminator (version 2) mix or $2 \mu \mathrm{l}$ of Big Dye Terminator (version 3.1) (both PE Applied Biosystems) were combined in a $10 \mu \mathrm{l}$ reaction volume. The primers used were the same as for PCR. Cycling conditions were 25 cycles of $96^{\circ} \mathrm{C}$ for 30 seconds, $55^{\circ} \mathrm{C}$ for 15 seconds, and $60^{\circ} \mathrm{C}$ for 4 minutes. Amplification products were precipitated with $120 \mu \mathrm{l} 70 \%$ isopropanol, washed with $70 \%$ isopropanol, and allowed to dry before being gel separated on an ABI377 or a ABI3730 automated sequencer at the Australian Genome Research Facility, Brisbane. Heterozygous base changes were confirmed by resequencing an independent PCR product. Sequencing chromatographs were confirmed by two independent researchers.

\section{Microsatellite genotyping}

Genotyping using the microsatellites PYGM, D11S4909, Dlis4938, and Dl1S4946 was performed using PCR in a total volume of $10 \mu \mathrm{l}$ containing 50-100 ng genomic DNA, $50 \mathrm{mmol} / \mathrm{l} \mathrm{KCl}, 1.5 \mathrm{mmol} / \mathrm{l} \mathrm{MgCl} 2,250 \mu \mathrm{mol} / \mathrm{l}$ each dATP, dTTP, and dGTP, $25 \mu \mathrm{mol} / \mathrm{l} \mathrm{dCTP}, 1 \mu \mathrm{Ci} \alpha{ }^{32} \mathrm{P}$ dCTP, $5 \mathrm{pmol}$ of each primer, and $0.5 \mathrm{U}$ AmpliTaq Gold (Perkin Elmer). Microsatellite primers have been previously described. ${ }^{12}{ }^{13}$ Reactions were amplified using the following conditions: $94^{\circ} \mathrm{C}$ for 10 minutes, followed by 30 cycles of $94^{\circ} \mathrm{C}$ for 1 minute, $55^{\circ} \mathrm{C}$ for 1 minute, and $72^{\circ} \mathrm{C}$ for 1.5 minutes. PCR products were separated by polyacrylamide gel electrophoresis, followed by autoradiography. In addition, the single nucleotide polymorphism D418D in exon 9 of the MENI gene was used to exclude a founder effect in some families.

\section{RESULTS}

\section{MEN1 mutation analysis}

Of the 150 patients analysed by our service, we found 55 had MEN1 mutations; 42 of the mutations were distinct and six occurred more than once (tables 1, 2). We found that 249253delGTCT occurred three times, $1268 \mathrm{G} \rightarrow \mathrm{A}$ and $1378 \mathrm{C} \rightarrow \mathrm{T}$ both occurred twice, 1546-1547ins $\mathrm{C}$ occurred seven times,
1546-1547delC occurred three times, and 1548-1549insG occurred twice. In order to determine if there were any common founders in the remaining families, we looked for allele sharing at the MENI locus in families that shared the same mutation (table 2). Using the microsatellite markers DliS4909, PYGM, D11S4946, and DIIS4938, and the D418D single nucleotide polymorphism, we were unable to exclude the possibility of a founder effect in five of the families with a 1546-1547insC mutation and two families with the 15481549insG mutation. Upon further investigation we were able to trace all of the five families that shared the 1546-1547insC mutation back to a common founder, resulting in a pedigree of eight generations. This extended family is now being phenotypically characterised.

We tested 85 index cases with a family history of MEN1 related disease including 23 cases with FIHP, 49 cases with a family history of hyperparathyroidism and one other MENI related tumour, 7 cases with a family history of pituitary tumour and neuroendocrine tumours, and 6 cases with familial isolated pituitary tumours (fig 1). We found a MEN1 mutation in $41 / 49(84 \%)$ of patients with a family history of hyperparathyroidism with at least one other MENl related condition. Family members of the eight MENl families without MENI mutations are now being recruited so that haplotyping of the MENI locus can be performed. All the cases with a family history of MEN1 related disease and a MENI mutation had a family history of hyperparathyroidism. We found MEN1 mutations in five of the 23 (22\%) FIHP families. Multiglandular parathyroid hyperplasia was reported in all five FIHP cases with MENI and 11 of the 18 FIHP cases without MENI mutations. Of the remaining seven cases, a single adenoma was reported in six cases and in one case, two adenomata were reported. We did not find MENI mutations in the 13 cases with a family history of MEN1 related tumours without familial hyperparathyroidism.

Of the 65 patients tested who lacked any family history of MEN1 related disease, 50 had hyperparathyroidism and at least one other MEN1 related condition, and 11 had sporadic hyperparathyroidism. We found that $8 / 50$ patients (16\%) with sporadic hyperparathyroidism and one other MEN1 related tumour had MENI mutations. In one of these cases we tested both parents and could not find a mutation in either parent. We found that $1 / 11$ cases $(9 \%)$ with sporadic hyperparathyroidism had a MEN1 mutation only. This patient was diagnosed at 20 years of age. MEN1 mutation testing on both parents of this individual proved negative. Of the 10 cases of sporadic hyperparathyroidism without MEN1 mutations, four cases were diagnosed before the age of 20 years and the remainder were cases with multiglandular parathyroid tumours (age range 50-66 years).

\section{Analysis of patients without MEN1 coding region mutations}

It is conceivable that mutations within the promoter could alter expression of the MEN1 gene, so we analysed $524 \mathrm{bp}$ of the promoter and 5'UTR (corresponding to the sequence between nucleotide 1234 and 1758 of Genbank accession no. U93237) in all patients who tested negative for mutations in the coding region. We found no sequence variations within this portion of the MENI gene promoter in any patient.

\section{DISCUSSION}

The data presented in this report support other studies showing that mutations within the MENI gene are scattered throughout the gene and in some cases have not been previously described. ${ }^{2} 4681032-38$ Consequently, testing for MENI mutations is a costly and time consuming process. In order to establish reasonable mutation testing criteria, we reviewed clinical features of all the index cases with MENI 


\begin{tabular}{|c|c|c|c|c|c|}
\hline Family & $\begin{array}{l}\text { Clinical risk } \\
\text { featurest of } \\
\text { proband }\end{array}$ & $\begin{array}{l}\text { MEN1related } \\
\text { tumourst of } \\
\text { family members }\end{array}$ & Mutation & $\begin{array}{l}\text { Effect on } \\
\text { protein }\end{array}$ & Reference \\
\hline 1 & $\mathrm{P}, \mathrm{Pl}, \mathrm{FH}$ & $P, P A$ & Deletion of exon 1 and 2 & Loss of start site & 8 \\
\hline 2 & $\mathrm{P}, \mathrm{FH}$ & $P$ & 13insACGCTdelGCC & Frameshift & \\
\hline 3 & $\mathrm{P}, \mathrm{G}, \mathrm{FH}$ & $\mathrm{PI}, \mathrm{G}$ & 74del15 & Frameshift & \\
\hline 4 & $\mathrm{P}, \mathrm{PI}, \mathrm{PA}, \mathrm{FH}$ & $\mathrm{P}, \mathrm{PI}, \mathrm{PA}, \mathrm{C}$ & 249-253delGTCT & Frameshift & $8,10,4$ \\
\hline 5 & $\mathrm{P}, \mathrm{FH}$ & $\mathrm{P}, \mathrm{PI}, \mathrm{PA}$ & 249-253delGTCT & Frameshift & $8,10,4$ \\
\hline 6 & $\mathrm{P}, \mathrm{PI}, \mathrm{FH}$ & $P, P I, P A, G$ & 249-253delGTCT & Frameshift & $8,10,4$ \\
\hline 7 & $\mathrm{P}, \mathrm{FH}$ & $P$ & 255 ins 19 & Frameshift & $8 \S$ \\
\hline 8 & $\mathrm{P}, \mathrm{Pl}, \mathrm{FH}$ & P, PI.PA, C & 269-271 delAT & Frameshift & 4 \\
\hline 9 & $P, G, C, F H$ & $P, G, C$ & $322 \mathrm{C} \rightarrow \mathrm{T}$ & $\mathrm{R} 108 \mathrm{X}$ & 4 \\
\hline 10 & $\mathrm{P}, \mathrm{PA}, \mathrm{FH}$ & P, PA & 404-405delA & Frameshift & \\
\hline 11 & $\mathrm{P}, \mathrm{PI}, \mathrm{PA}, \mathrm{FH}$ & $P, P I, P A, G, C, L$ & IVS2-3C $\rightarrow \mathrm{G}$ & Splicing error & 10 \\
\hline 12 & P, PI, PA & & $571 \mathrm{G} \rightarrow \mathrm{T}$ & E191X & 4 \\
\hline 13 & $\mathrm{P}, \mathrm{FH}$ & $P$ & $590 \mathrm{C} \rightarrow \mathrm{T}$ & T1971 & \\
\hline 14 & $\mathrm{P}, \mathrm{PI}$ & & 625-629delCAGA & Frameshiff & \\
\hline 15 & $\mathrm{P}, \mathrm{FH}$ & $\mathrm{P}, \mathrm{PI}$ & 631-635delGTCA & Frameshift & \\
\hline 16 & $\mathrm{P}, \mathrm{Pl}, \mathrm{FH}$ & $\mathrm{P}, \mathrm{PI}, \mathrm{PA}, \mathrm{C}$ & $\mathrm{IVS} 3+1 \mathrm{G} \rightarrow \mathrm{T}$ & Splicing error & 10 \\
\hline 17 & $\mathrm{P}, \mathrm{C}, \mathrm{FH}$ & $\mathrm{P}, \mathrm{PA}, \mathrm{C}, \mathrm{L}$ & $660 G \rightarrow A$ & W220X & 8 \\
\hline 18 & $\mathrm{P}, \mathrm{FH}$ & $G, C$ & $686 \mathrm{G} \rightarrow \mathrm{T}$ & R229L & $4,8,10$ \\
\hline 19 & $\mathrm{P}, \mathrm{Pl}, \mathrm{PA}, \mathrm{G}, \mathrm{FH}$ & $P, G$ & IVS4+1G $\rightarrow T$ & Splicing error & 10 \\
\hline 20 & $P, P A, G$ & & $772 \mathrm{C} \rightarrow \mathrm{T}$ & Q258X & 9 \\
\hline 21 & $\mathrm{P}, \mathrm{C}, \mathrm{FH}$ & $P, G$ & $851 \mathrm{C} \rightarrow \mathrm{A}$ & A284E & \\
\hline 22 & $\mathrm{P}, \mathrm{PI}, \mathrm{PA}$ & & IVS5+1G $\rightarrow$ A & Splicing error & 33 \\
\hline 23 & $\mathrm{P}, \mathrm{PI}, \mathrm{FH}$ & $P, G$ & $1010 \mathrm{C} \rightarrow \mathrm{A}$ & A337D & 34 \\
\hline 24 & $P, G, A, F H$ & $P, G$ & $1056 \mathrm{~T} \rightarrow \mathrm{G}$ & Y353D & \\
\hline 25 & $\mathrm{P}, \mathrm{FH}$ & $\mathrm{P}$ & 1057-1060delACT & Y353del & \\
\hline $26+$ & $\mathrm{P}, \mathrm{PI}, \mathrm{G}, \mathrm{FH}$ & $P$ & $1117 \mathrm{C} \rightarrow \mathrm{T}$ & P373S & 8 \\
\hline 27 & $\mathrm{P}, \mathrm{PI}, \mathrm{G}, \mathrm{FH}$ & $\mathrm{P}, \mathrm{PI}$ & $1227 \mathrm{C} \rightarrow \mathrm{A}$ & C409X & \\
\hline 28 & $\mathrm{P}, \mathrm{PI}, \mathrm{G}, \mathrm{C}, \mathrm{FH}$ & $\mathrm{P}, \mathrm{PI}$ & $1244 G \rightarrow C$ & R415P & 8 \\
\hline 29 & $\mathrm{P}, \mathrm{FH}$ & $\mathrm{P}, \mathrm{PI}, \mathrm{G}, \mathrm{C}$ & $1252 \mathrm{G} \rightarrow \mathrm{C}$ & $\mathrm{D} 419 \mathrm{H}$ & \\
\hline 30 & $\mathrm{P}, \mathrm{C}, \mathrm{FH}$ & P, PI, PA, C & $1268 \mathrm{G} \rightarrow \mathrm{A}$ & W423X & 8 \\
\hline 31 & $\mathrm{P}, \mathrm{PA}, \mathrm{C}, \mathrm{FH}$ & $\mathrm{P}$ & $1268 \mathrm{G} \rightarrow \mathrm{A}$ & W423X & 8 \\
\hline 32 & $\mathrm{P}, \mathrm{PA}, \mathrm{FH}$ & $\mathrm{P}, \mathrm{C}$ & 1304-1305delG & Frameshift & 35 \\
\hline 33 & $\mathrm{P}, \mathrm{PI}, \mathrm{G}, \mathrm{C}, \mathrm{FH}$ & $P, G, L$ & 1342-IVS9+2del & Frameshift & 36 \\
\hline 34 & $\mathrm{P}, \mathrm{PI}, \mathrm{PA}, \mathrm{A}$ & & $1378 \mathrm{C} \rightarrow \mathrm{T}$ & R460X & $4,6,8$ \\
\hline 35 & $P, P A, G, C$ & & $1378 \mathrm{C} \rightarrow \mathrm{T}$ & R460X & $4,6,8$ \\
\hline 36 & $\mathrm{P}, \mathrm{PI}, \mathrm{G}, \mathrm{C}, \mathrm{FH}$ & $?$ & $1410 \mathrm{C} \rightarrow \mathrm{T}$ & Q450X & 37 \\
\hline 37 & $\mathrm{P}, \mathrm{G}, \mathrm{FH}$ & $P, G$ & IVS9del-13-+1 & Splicing error & \\
\hline 38 & $\mathrm{P}, \mathrm{PI}, \mathrm{PA}, \mathrm{FH}$ & $\mathrm{P}, \mathrm{PI}$ & $1546-1547 \mathrm{delC}$ & Frameshift & $4,6,34$ \\
\hline 39 & $\mathrm{P}$ & & $1546-1547 \mathrm{del} C$ & Frameshift & $4,6,34$ \\
\hline 40 & $\mathrm{P}, \mathrm{PA}, \mathrm{PI}, \mathrm{FH}$ & $\mathrm{P}, \mathrm{PI}$ & $1546-1547 \mathrm{del} C$ & Frameshift & $4,6,34$ \\
\hline $41 \ddagger$ & $\mathrm{P}, \mathrm{PI}, \mathrm{PA}, \mathrm{FH}$ & $P, P I, P A, G, C, L$ & 1546-1547insC & Frameshift & $4,6,8,10,34$ \\
\hline $42^{\top}$ & $\mathrm{P}, \mathrm{FH}$ & $\mathrm{P}$ & 1546-1547insC & Frameshift & $4,6,8,10,34$ \\
\hline 43 & $\mathrm{P}, \mathrm{PI}, \mathrm{PA}, \mathrm{FH}$ & $\mathrm{P}$ & 1546-1547ins C & Frameshift & $4,6,8,10,34$ \\
\hline 44 & $\mathrm{P}, \mathrm{FH}$ & $P, G$ & 1548-1549insG & Frameshift & \\
\hline 45 & $\mathrm{P}, \mathrm{PA}, \mathrm{FH}$ & $P^{\prime}$ & 1548-1549insG & Frameshift & \\
\hline 46 & $P, P A$ & & 1556-1557insT & Frameshift & 37 \\
\hline 47 & $\mathrm{P}, \mathrm{PI}, \mathrm{PA}$ & & $1579 \mathrm{C} \rightarrow \mathrm{T}$ & R527X & 10 \\
\hline 48 & $\mathrm{P}, \mathrm{Pl}, \mathrm{FH}$ & $\mathrm{P}, \mathrm{PA}$ & 1590 delA, $1592 \mathrm{G} \rightarrow \mathrm{C}$ & Frameshift & 38 \\
\hline 49 & $P, P A, G, L, F H$ & $P, G, L$ & $1688 \mathrm{~A} \rightarrow \mathrm{T}, 1693-1694 \mathrm{delCT}$ & Frameshift & \\
\hline 50 & $\mathrm{P}, \mathrm{L}, \mathrm{FH}$ & $P, P I, G, L$ & $1701 \mathrm{delC}$ & Frameshift & \\
\hline \multicolumn{6}{|c|}{$\begin{array}{l}\text { P, hyperparathyroidism; PI, pituitary tumour; PA, endocrine pancreatic tumour; G, gastrinoma or Zollinger-Ellison } \\
\text { syndrome; C, carcinoid; L, lipoma; A, adrenal tumour/hyperplasia. The nucleotide numbering begins at the A of the } \\
\text { ATG of the initiator Met codon as per recommendations of the Nomenclature Working Group. }{ }^{39} \text { tFamily } 26 \text { was } \\
\text { originally found as two separate families but subsequently found to be related. } \neq \text { Family } 41 \text { was originally found as five } \\
\text { separate families but subsequently found to be related. } \$ \text { This mutation was previously incorrectly reported as } 256 \text { ins } 18 .^{8}\end{array}$} \\
\hline
\end{tabular}

mutations and found that they all had hyperparathyroidism or a family history of hyperparathyroidism. In addition, $22 \%$ of FIHP index cases had a MENI mutation. We did not detect any MENl mutations in seven cases with a family history of pituitary tumour and neuroendocrine tumours nor in six cases with familial isolated pituitary tumours. This finding supports previous studies showing a lack of MENI mutations in cases with familial isolated pituitary tumours. ${ }^{10}$ From these data, we conclude that all patients with familial hyperparathyroidism should be tested for MENI mutations.

In this report we found that $16 \%$ of apparently sporadic cases of hyperparathyroidism and one other tumour had a MENI germline mutation. In one of these cases we were able to demonstrate that the mutation was de novo. However as MEN1 is reported to be $100 \%$ penetrant by 60 years of age, it is likely that the remaining cases are also de novo mutations.
Previous studies have reported a de novo rate of approximately $10 \%{ }^{49}$ As the numbers reported in this study are subject to the biases of the referring clinicians, we cannot compare our findings with others.

Interestingly, we found a MEN1 mutation in $1 / 11$ cases (9\%) with sporadic hyperparathyroidism. A recent study reported MEN1 germline mutations in 5\% of apparently sporadic hyperparathyroidism patients. ${ }^{14}$ Although our data support this finding, the numbers tested in this report are not enough to make a definite conclusion with regard to testing criteria. In addition, the patients included in our report had either multiglandular disease or hyperparathy-roidism at a young age and thus are a biased sample population of patients with sporadic hyperparathyroidism. Further investigations are needed to determine the MENI mutation detection rate of patients with sporadic hyperparathyroidism. 


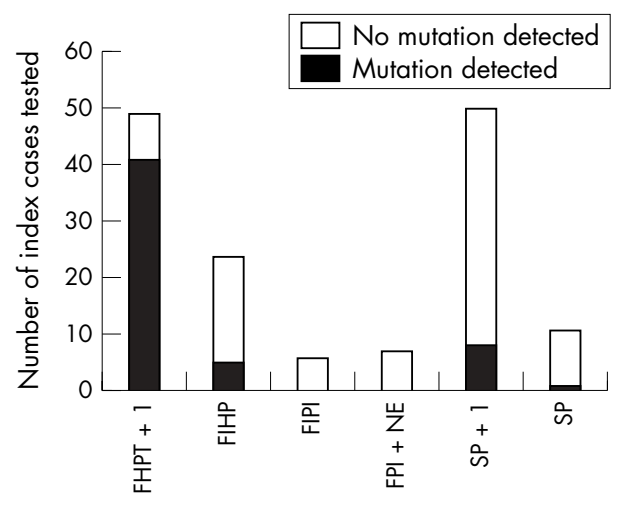

Figure 1 MEN1 mutations detected in index cases with MEN1 related conditions. The index cases tested are grouped as familial hyperparathyroidism plus one other MEN1 related condition (FHPT+1), familial isolated hyperparathyroidism (FIHP), familial isolated pituitary tumours (FIPI), family history of pituitary tumour and a neuroendocrine tumour $(\mathrm{FPI}+\mathrm{NE})$, sporadic hyperparathyroidism plus one other MENI related condition (SP+1), and sporadic hyperparathyroidism (SP).

Because of the costs involved, MENI mutation testing on all cases of primary hyperparathyroidism is impractical. We therefore suggest that MENI mutation testing be performed on patients with multiglandular parathyroid hyperplasia that present at a young age, as the typical age of presentation of hyperparathyroidism in MENl patients is 20-25 years old, 30 years younger than the majority of patients with hyperparathyroidism. ${ }^{15} 16$ All FIHP patients with a MENI mutation in this report had multiglandular disease, and the age of diagnosis for the single case of primary hyperparathyroidism with a germline MENl mutation was 20 years old. In support of this, Langer et al ${ }^{17}$ recently reported a similar finding with $2 / 15$ cases of apparently sporadic multiglandular hyperparathyroidism having MEN1 germline mutations. We also recommend that serum calcium and parathyroid hormone be routinely measured in the families of all primary hyperparathyroidism patients that have multiglandular disease, as a number of our familial hyperparathyroidism probands presented without apparent family history. However, upon further investigation by the referring clinician, a family history of hyperparathyroidism was established. Therefore we suggest that biochemical studies of additional family members in apparently sporadic cases of hyperparathyroidism should always precede more expensive MENI mutation testing.

This is the first large study to investigate the involvement of a region reported ${ }^{18}$ to be the $M E N 1$ promoter in MENI gene mutation negative patients with MENl-like syndromes. To date, no germline or somatic $M E N 1$ promoter mutations have been reported. ${ }^{19-21}$ This finding does not exclude mutations within other untranscribed or untranslated regions of the gene or large deletions of entire exons contributing to the disease. We report eight families with a family history of hyperparathyroidism and one other MENl related tumour. Future haplotype studies in these families will be of interest.

Hyperparathyroidism is the most common and earliest presenting MEN 1 related condition. Over 95\% of patients with MENI gene mutations have hyperparathyroidism. ${ }^{22}{ }^{23}$ It is not surprising that we found that all of our mutation positive families involved multiple cases of hyperparathyroidism and that we were able to detect a MENI gene mutation in 5/23 of patients with FIHP. Familial hyperparathyroidism is also a common syndrome in familial hyperparathyroidism and jaw tumour syndrome (FHPT-JT). Mutations in the HRPT2 gene have recently been identified in a large percentage of families with FHPT-JT. ${ }^{24}{ }^{25}$ However, mutations in HRPT2 appear to be uncommon in FIHP families. ${ }^{27}$ In contrast, the presence of inactivating mutations of the calcium sensing receptor has been reported in 14-18\% of familial FIHP cases. ${ }^{26} 27$

Approximately $25 \%$ of gastrinoma cases have MEN1 syndrome. To date there have been no large studies investigating the presence of germline MEN1 mutations in familial isolated gastrinoma cases, which probably reflects the rare occurrence of this syndrome without the presence of hyperparathyroidism. Somatic MENI mutations have been reported in approximately one third of sporadic gastrinomas, and there has been one report of a germline MENI mutation in a patient with no family history of MEN1. ${ }^{28-30}$ With the exception of insulinomas, many clinicians believe surgery is contraindicated in MENl patients with enteropancreatic lesions, and so the finding of a germline MENl mutation can significantly change the surgical management of a patient. It has therefore been suggested that consideration should be given to MENI mutation testing of sporadic cases of Zollinger-Ellison cases. ${ }^{2}$ Further investigations of MENI detection rates in sporadic Zollinger-Ellison syndrome are warranted.

Recently, in situ immunofluorescence analysis of neuroendocrine tumours showed a lack of menin expression in a case with a germline mutation in MENI and loss of the wild type allele. ${ }^{31}$ Although this was only a pilot study, it raises the possibility of an alternative and possibly more cost effective method of testing for MENI mutations in sporadic cases of hyperparathyroidism and Zollinger-Ellison syndrome.

In conclusion, our data indicate that routine germline MENI mutation testing by national testing services of all cases of "classical" MEN1, familial hyperparathyroidism, and sporadic hyperparathyroidism with one other MENI related condition is justified. However, routine testing of the promoter region between nucleotide 1234 and 1758

Table 2 MEN1 gene locus haplotype analysis of families with recurrent MEN1 gene mutations

\begin{tabular}{|c|c|c|c|c|c|c|c|c|c|c|c|c|c|c|c|c|}
\hline \multirow[b]{3}{*}{ Family no. } & \multicolumn{16}{|c|}{ Haplotypes } \\
\hline & \multicolumn{3}{|c|}{ 249-253delTCT } & \multicolumn{7}{|c|}{$1546-1547$ ins $C$} & \multicolumn{2}{|c|}{$1546-1547$ delC } & \multicolumn{2}{|c|}{ 1548-1549insG } & \multicolumn{2}{|c|}{$1268 G \rightarrow A$} \\
\hline & 4 & 5 & 6 & 41 & 41 & 43 & 41 & 41 & 41 & 42 & 38 & 40 & 44 & 45 & 30 & 31 \\
\hline D11S4909 & $5 / 9$ & $1 / 3$ & $8 / 8$ & 9 & 9 & $5 / 7$ & 9 & 9 & 9 & $3 / 3$ & $4 / 8$ & $9 / 9$ & $4 / 9$ & $4 / 4$ & $7 / 9$ & $1 / 10$ \\
\hline PYGM & $8 / 9$ & 11 & $7 / 8$ & 7 & 7 & $3 / 9$ & 7 & 7 & 7 & $1 / 2$ & $8 / 8$ & $8 / 10$ & $1 / 6$ & $3 / 4$ & $14 / 14$ & $4 / 5$ \\
\hline MENI D418D & $\mathrm{T}$ & C & - & - & - & - & - & - & - & - & - & - & $\mathrm{T}$ & $\mathrm{C} / \mathrm{T}$ & - & - \\
\hline D11S4946 & $4 / 5$ & $4 / 5$ & $2 / 2$ & 4 & 4 & $2 / 6$ & 4 & 4 & 4 & $4 / 4$ & $2 / 2$ & 5 & 4 & $4 / 5$ & $1 / 3$ & 5 \\
\hline D11S4938 & $1 / 3$ & $3 / 3$ & $3 / 3$ & 1 & 1 & $1 / 3$ & 1 & 1 & 1 & $2 / 3$ & $1 / 1$ & $1 / 5$ & $3 / 3$ & $1 / 3$ & $1 / 3$ & $3 / 3$ \\
\hline
\end{tabular}

The proband of each family was typed for the microsatellite markers D1 1S4909, PYGM, D1 1S4946, and D1 1S4938, and in the case of families 3 and 4, for the D419D single nucleotide polymorphism in exon 9 of MEN1. For probands sharing the same mutation and at least one microsatellite allele, only the affected allele is shown. In some cases, families with more than one affected family member were genotyped, allowing the identification of the linked allele. The linked allele was determined by looking for allele sharing between affected individuals within each of the families (data not shown). Patients with sporadic MEN1 were not genotyped, including one patient with 1546-1547delC and the two patients with 1378C $\rightarrow T$. 
(Genbank accession no. U93237) is not recommended, as this region does not account for the proportion of MENl cases that lack coding sequence and splice site mutations. Although our data are not conclusive and more investigations are warranted, we also suggest that testing of patients who develop sporadic hyperparathyroidism with multigland hyperplasia before the age of 30 years be considered. Further studies are recommended to assess the justification of screening patients with Zollinger-Ellison syndrome without a family history of MEN1.

\section{Authors' affiliations}

J W Cardinal, L Marks, J B Prins, D P Cameron, Department of Diabetes and Endocrinology, Princess Alexandra Hospital, Brisbane, Australia L Bergman, N Hayward, Human Genetics Laboratory, Queensland Institute of Medical Research, Brisbane, Australia

A Sweet, J Warner, J B Prins, Department of Medicine, University of Queensland, Brisbane, Australia

D Learoyd, T Dwight, B Robinson, Kolling Institute of Medical Research, Royal North Shore Hospital and University of Sydney, Sydney, Australia M Epstein, Private Endocrinologist, Newcastle, Australia

M Smith, Pathology Department, Royal Melbourne Hospital, Melbourne, Australia

B T Teh, Laboratory of Cancer Genetics, Van Andel Research Institute, Grand Rapids, USA

Competing interests: none declared

\section{REFERENCES}

1 Wermer P. Genetic aspects of adenomatosis of endocrine glands. Am J Med 1954; 16:363-7.

2 Brandi ML, Gagel RF, Angeli A, Bilezikian JP, Beck-Peccoz P, Bordi C, ConteDevolx B, Falchetti A, Gheri R, Libroia A, Lips CJM, Lombardi G, Mannelli M, Pacini F, Ponder BAJ, Rave F, Skogseid B, Tamburrano G, Thakker RV, Thompson NW, Tomassetti P, Tonelli F, Wells SA, Marx SJ. Guidelines for diagnosis and therapy of MEN type 1 and type 2. J Clin Endocrinol Metab 2001;86:5658-71.

3 Metz DC, Jensen RT, Bale AE, Skarulis MC, Eastman RC, Nieman L, Norton JA et al. Multiple endocrine neoplasia type 1: clinical features and management. In: Bilezikian JP Levine MA, Marcus R, Friedman E, Larsson C, Amorosi A, Bernadi ML, Marx SJ. The parathyroids. New York: Raven Press, 1994:591-645

4 Basset JHD, Forbes SA, Pannett AAJ, Lloyd SE, Christie PT, Wooding C, Harding B, Besser GM, Edwards CR, Monson JP, Sampson J, Wass JAH, Wheeler $M H$, Thakker RV. Characterisation of mutations in patients with multiple endocrine neoplasia type 1. Am J Hum Genet 1998;62:232-44.

5 Crabtree JS, Scacheri PC, Ward JM, Garrett-Beal L, Emmert-Buck MR, Edgemon KA, Lorang D, Libutti SK, Chandrasekharappa SC, Marx SJ, Spiegel AM, Collins FS. 2001 A mouse model of multiple endocrine neoplasia, type 1, develops multiple endocrine tumors. Proc Natl Acad Sci USA 98: $1118-23$

6 Agarwal SK, Kester MB, Debelenko LV, Heppner C, Emmert-Buck MR, Skarulis MC, Doppman JL, Kim YS, Lubensky IA, Zhuang Z, Green JS, Guru SC, Manickam P, Olufemi SE, Liotta LA, Chandraasekharappa SC, Collins FS, Spiegel AM, Burns AL, Marx SJ. Germline mutations of the MENI gene in familial multiple endocrine neoplasia type 1 and related states. Hum Mol Genet 1997:6:1169-75.

7 Bardin T. Primary hyperparathyroidism. Clinical, epidemiological and histological aspects. Ann Endocrinol 1994;55:143-6.

8 Bergman L, Teh B, Cardinal J, Palmer J, Walters M, Shepherd J, Cameron D, Hayward N. Identification of MEN1 gene mutations in families with MEN1 and related disorders. Br J Med 2000;83:1009-14.

9 Poncin J, Abs R, Velkeniers B, Bonduelle M, Abramowicz M, Legros JJ, Verloes A, Meurisse M, Van Gaal L, Verellen C, Koulischer L, Beckers A. Mutation analysis of the MEN1 gene in Belgian patients with multiple endocrine neoplasia type 1 and related diseases. Hum Mutat 1999:13:54-60.

10 Teh BT, Kytola S, Farnebo F, Bergman L, Wong FK, Weber G, Hayward N, Larsson C, Skogseid B, Beckers A, Phelan C, Edwards M, Epstein M, Alford F Hurley D, Grimmond S, Silins G, Walters M, Stewart C, Cardinal J, Khodaei S Parente F, Tranebjaerg L, Jorde R, Menon J, Khir A, Tan T, Chan SP, Zaini A Khalid BAK, Sandelin K, Thompson N, Brandi M-L, Warth M, Stock J, Leisti J, Cameron D, Shepherd JJ, Oberg K, Nordenskjold M, Salmela P. Mutation analysis of the MEN1 gene in multiple endocrine neoplasia type 1, familial acromegaly and familial isolated hyperparathyroidism. J Clin Endocrinol Metab 1998;83:2621-6.

11 Miller SA, Dykes DD, Polesky HF. A simple salting out procedure for extracting DNA from human nucleated cells. Nucleic Acid Res 1998;16:1215.

12 Karges W, Jostarndt K, Maier S, Flemming A, Weitz M, Wissmann A, Feldmann B, Dralle H, Wagner P, Boehm BO. Multiple endocrine neoplasia type 1 (MEN1) gene mutations in a subset of patients with sporadic and familial primary hyperparathyroidism target the coding sequence but spare the promoter region. J Endocrinol 2000;166:1-9.
13 Manickam P, Guru SC, Debelenko LV, Agarwal SK, Olufemi S, Weisemann JM, Boguski MS, Crabtree JS, Wang Y, Roe BA, Lubensky IA, Zhuang Z, Kester MB, Burns AL, Spiegel AM, Marx SJ, Liotta LA, EmmertBuck MR, Collins FS, Chandrasekharappa SC. Eighteen new polymorphic markers in the multiple endocrine neoplasia type 1 (MEN1) region. Hum Genet 1997; 101:102-8.

14 Uchino S, Noguchi S, Sato M, Yamashita H, Watanabe S, Murakami T, Toda M, Ohshima A, Futata T, Mizukoshi T, Koike E, Takatsu K, Terao K Wakiya S, Nagatomo M, Adachi M. Screening of the Menl gene and discovery of germ-line and somatic mutations in apparently sporadic parathyroid tumours. Cancer Res 2000;60:5553-7.

15 Marx S, Spiegel AM, Skarulis MD, Doppman JL, Collins FS, Liotta LA. Multiple endocrine neoplasia type 1: Clinical and genetic topics. Ann Intern Med $1998 ; 129: 484-94$

16 Mallette LE, Bilezikian JP, Heath DA, Aurbach GD. Primary hyperparathyroidism: clinical and biochemical features. Medicine 1974;53:127-46.

17 Langer P, Wild A, Hall A, Celik I, Rothmund M, Bartsch DK. Prevalence of multiple endocrine neoplasia type 1 in young patients with apparently sporadic primary hyperparathyroidism or pancreaticoduodenal endocrine tumours. Br J Surg 2003;90:1599-603.

18 Vanbellinghen J-F, Beckers A, Poncin J. Preliminary characterization of the promoter and cis-regulatory elements of the MEN1 gene. Presented at the Seventh International MEN Workshop, Gubbio, Italy, 30 June, 1999.

19 Karges W, Maier S, Schmidt F, Gress TM, Boehm BO. Role of the MEN1 tumour suppressor gene in human ductal pancreatic cancer. Cancer Lett 2000;157:51-5.

20 Karges W, Jostarndt K, Maier S, Flemming A, Weitz M, Wissmann A Feldmann B, Dralle H, Wagner P, Boehm BO. Multiple endocrine neoplasia type 1 (MEN1) gene mutations in a subset of patients with sporadic and familial primary hyperparathyroidism target the coding sequence but spare the promoter region. J Endocrinol 2000;166:1-9.

21 Namihira H, Sato M, Matsubara S, Ohye H, Bhuiyan M, Murao K, Takahara J. No evidence of germline mutation or somatic deletion of the MEN1 gene in a case of familial multiple endocrine neoplasia typel (MEN1). Endocr J 1999;46:811-16.

22 Benson L, Ljunghall S, Akerstrom G, Oberg K. Hyperparathyroidism presenting as the first lesion in multiple endocrine neoplasia type 1. Am J Med 1987;82:731-7.

23 Trump D, Farren B, Wooding C, Pang JT, Besser GM, Buchanan KD, Edwards CR, Heath DA, Jackson CE, Jansen S, Lips K, Monson J, O'Halloran D, Sampson J, Shalet SM, Wheeler MH, Zink A, Thakker RV. Clinical studies of multiple endocrine neoplasia type 1 (MEN1) in 220 patients. Quarterly J Med 1996;89:653-69.

24 Hobbs MR, Pole AR, Pidwirny GN, Rosen IB, Zarbo RJ, Coon H, Heath H 3rd, Leppert M, Jackson CE. Hyperparathyroidism-jaw fumor syndrome: the HRPT2 locus is within a $0.7-\mathrm{cM}$ region on chromosome lq. Am J Hum Genet 1999;64:518-25.

25 Carpten JD, Robbins CM, Villablanca A, Forsberg L, Presciuttini S, BaileyWilson J, Simonds WF, Gillanders EM, Kennedy AM, Chen JD, Agarwal SK, Sood R, Jones MP, Moses TY, Haven C, Petillo D, Leotlela PD, Harding B, Cameron D, Pannett AA, Hoog A, Heath HIII H, James-Newton LA, Robinson B, Zarbo RJ, Cavaco BM, Wassif W, Perrier ND, Rosen IB, Kristoffersson U, Turnpenny PD, Farnebo LO, Besser GM, Jackson CE, Morreau H, Trent JM, Thakker RV, Marx SJ, Teh BT, Larsson C, Hobb MR. HRPT2, encoding parafibromin, is mutated in hyperparathyroidism-jaw tumor syndrome. Nature Genet 2002;32:676-80.

26 Simonds WF, James-Newton LA, Agarwal SK, Yang B, Skarulis MC, Hendy GN, Marx SJ. Familial isolated hyperparathyroidism: clinical and genetic characteristics of 36 kindreds. Medicine 2002;81:1-26.

27 Warner J, Epstein M, Sweet A, Singh D, Burgess J, Stranks S, Hill P, PerryKeene D, Learoyd D, Robinson B, Birdsey P, Mackenzie E, Teh BT, Prins JB, Cardinal J. Genetic testing in familial isolated hyperparathyroidism: unexpected results and their implications. J Med Genet 2003:41:155-60.

28 Roy PK, Venzon DJ, Shojamanesh H, Abou-Saif A, Peghini P, Doppman JL, Gibril F, Jensen RT. Zollinger-Ellison syndrome. Clinical presentation in 261 patients. Medicine 2000;79:379-411.

29 Zhuang Z, Vortmeyer AO, Pack S, Huang S, Pham TA, Wang C, Park WS Agarwal SK, Debelenko LV, Kester M, Guru SC, Manickam P, Olufemi SE, Heppner C, Crabtree JS, Skarulis MC, Venzon DJ, Emmert-Buck MR, Spiegel AM, Chandrasekharappa SC, Collins FS, Burns AL, Marx SJ', Lubensky IA. Somatic mutations of the MEN1 tumor suppressor gene in sporadic gastrinomas and insulinomas. Cancer Res 1997;57:4682-6.

30 Goebel SU, Heppner C, Burns AL, Marx SJ, Spiegel AM, Zhuang Z, Lubensky IA, Gibril F, Jensen RT, Serrano J. Genotype/phenotype correlation of multiple endocrine neoplasia type 1 gene mutations in sporadic gastrinomas. J Clin Endocrinol Metab 2000;85:116-23.

31 Cavallari I, D'Agostino DM, Ferro T, Rosato A, Barzon L, Pasquali C, Fogar P, Theodoropoulou M, Esposito G, Boscaro M, Pagotto U, Tebaldi E, Fallo F, Chieco-Bianchi L, Ciminale V. In situ analysis of human menin in normal and neoplastic pancreatic tissues: evidence for differential expression in exocrine and endocrine cells. J Clin Endocrinol Metab 2003;88:3893-901.

32 Chandrasekharappa SC, Guru SC, Manickam P, Olufemi S-E, Collins FS Emmert-Buck MR, Debelenko LV, Zhuang Z, Lubensky IA, Liotta LA Crabtree JS, Wang Y, Roe B, Weisemann J, Boguski MS, Agarwal SK, Kester MB, Kim YS, Heppner C, Dong Q, Spiegel AM, Burns AE, Marx SJ. Positional cloning of the gene for multiple endocrine neoplasia type 1. Science 1997;276:404-7.

33 Heppner C, Kester MB, Agarwal SK, Debelenko LV, Emmert-Buck MR, Guru SC, Manickam P, Olufemi SE, Skarulis MC, Doppman JL, Alexander RH, Kim YS Sagger SK, Lubensky IA, Zhuang Z, Liotta LA, Chandrasekharappa SC, 
Collins FS, Spiegel AM, Burns AL, Marx SJ. Somatic mutation of the MENI gene in parathyroid tumours. Nat Genet 1997;16:375-8.

34 Giraud S, Zhang CX, Serova-Sinilnikova O, Wautot V, Salandre J, Buisson N, Waterlot C, Bauters C, Porchet N, Aubert J-P, Emy P, Cadiot G, Delemer B, Chabre O, Niccoli P, Leprate F, Duron F, Emperauger B, Cougard P, Goudet P, Sarfati E, Riou J-P, Guichard S, Rodier M, Meyrier A, Caron P, Vantyghem M-C, Assayag M, Peix J-L, Pugeat M, Rohmer V, Vollotton M, Lenoir G, Gaudray P, Proye C, Conte-Devolx B, Chanson P, Shugart YY, Goldgar D, Murat A, Calender A. Germ-line mutation analysis in patients with multiple endocrine neoplasia type 1 and related disorders. Am J Hum Genet 1998;63:455-67.

35 Bartsch D, Kopp I, Bergenfelz A, Rieder H, Munch K, Jager K, Deiss Y, Schudy A, Barth P, Arnold R, Rothmund M, Simon B. MEN1 gene mutations in $12 \mathrm{MENI}$ families and their associated tumors. Eur I Endocrinol 1998:139:416-20.
36 Dackiw AP, Cote GJ, Fleming JB, Schultz PN, Stanford P, VassilopoulouSellin R, Evans DB, Gagel RF, Lee JE. Screening for MEN1 mutations in patients with atypical endocrine neoplasia. Surgery 1999;126:1097-103.

37 Hai N, Aoki N, Matsuda A, Mori T, Kosugi S. Germline MEN1 mutations in sixteen Japanese families with multiple endocrine neoplasia type 1 (MEN1). Eur J Endocrinol 1999;141:475-80.

38 Debelenko LV, Brambilla E, Agarwal SK, Swalwell Jl, Kester MB, Lubensky IA, Zhuang Z, Guru SC, Manickam P, Olufemi SE, Chandrasekharappa SC, Crabtree JS, Kim YS, Heppner C, Burns AL, Spiegel AM, Marx SJ, Liotta LA, Collins FS, Travis WD, Emmert-Buck MR. Identification of MEN1 gene mutations in sporadic carcinoid tumors of the lung. Hum Mol Genet 1997;6:2285-90

39 Antonarakis SE, the Nomenclature Working Group. Recommendations for a nomenclature system for human gene mutations. Hum Mut 1998:11:1-3. 